\title{
FROM THE
}

\section{Center of $\Phi_{\text {nternational }} \int_{\text {tudies }}$}

PRINCETON U NIVERSITY

\section{THE FUTURE OF THE}

\section{INTERNATIONAL LEGAL ORDER}

Volume III, Conflict Management

Edited by Cyril E. Black and Richard A. Falk

Eleven contributors come to grips with the realities of controlling war in our modern, interrelated world. All of them deal directly with the role of law in the management of conflict.

Order from your bookstore, or

Princeton University Press

Princeton, New Jersey 08540

\section{A COMPARATIVE APPROACH \\ TO THE STUDY OF FOREIGN POLICY:}

Notes on Theorizing

By Edward L. Morse

A vocabulary for analyzing foreign policy objectives on a comparative basis is mapped out in the author's effort to refocus the comparative study of foreign policy on substantive rather than procedural aspects of statecraft.

Research Monograph No. 36

Order from the

Center of International Studies

Corwin Hall, Princeton, N.J. 08540 